\title{
Mapping of Ground Water Quality of Injana Aquifer South of Sinjar Anticline /Northern Iraq
}

\author{
Umar N. Abdul Qader \\ Department of Soil and water Science \\ College of Agriculture and Forestry \\ Mosul University
}

(Received 13/7/2008 , Accepted 19/3/2009)

\begin{abstract}
Fourteen ground water samples were collected from deep wells from Al-Adnanya Sinjar area. Major hydrochemical parameters were studied to understand the quality of water. The objective of this study is to map the ground water quality of Injana aquifer and to delineate the areal extent of good and poor water. Two types of ground water were recognized in the study area, according to chemical analysis and utilizing the Hierarchical Cluster Analysis (HCA), bicarbonate type and sulphate type, the sulphate type of water is dominant with high concentration of total dissolved solids, total hardness, magnesium and sulphate comparing with bicarbonate type. Mapping results showed that water occur in Telkasab and Al-Kahtanya (poor quality) is unsuitable for drinking, while water occur in Sinjar, Domise, and Rambosy (high quality) desirable for drinking, and water occur in Al-Adnanya and Al-Jazera are not exceeding the maximum permissible limit for drinking. Dissolution of rocks and salts in soil, ion exchange and limited reverse ion exchange in few parts of the area are the main processes controlling the chemistry of ground water. Based on hydrochemical ratio $\left(\mathrm{HCO}_{3} / \mathrm{Cl}\right) 71 \%$ of the wells were located in recharge zone and $29 \%$ were located in discharge zone.
\end{abstract}

\section{لوم خاولة لنوعية الميل الجوفية لخزل الججلا جنوبطيفسنجار/سشمل العراق}

\author{
عمر نبهلن عبدالفالر

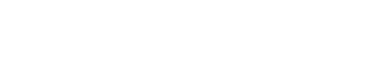 \\ كلية الرراعة والغابلت \\ جلمعة الموصل
}

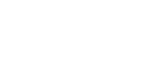

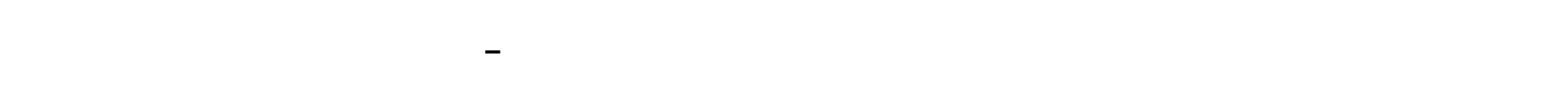

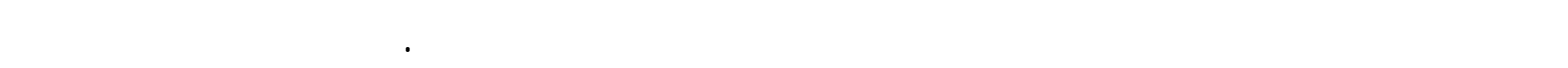

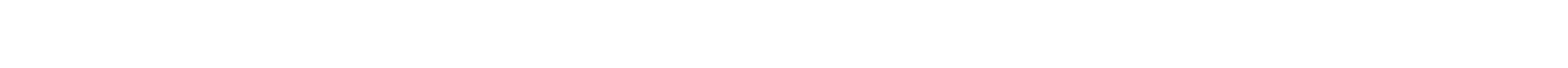


الجيلة والرديئة .م تميز نوعين من الميه في المظقة بالاعتماد على نتائج التحاليل الكيمائية ونتائج قطبق

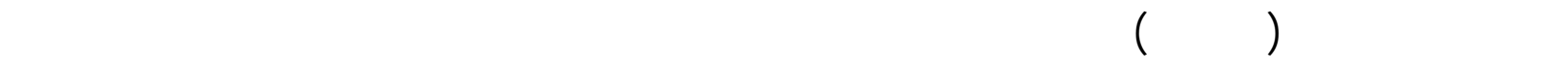

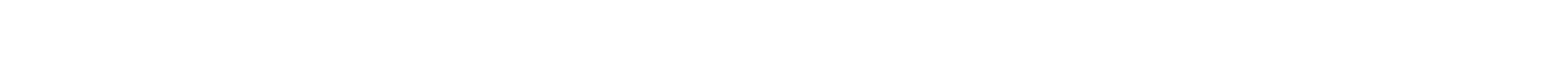

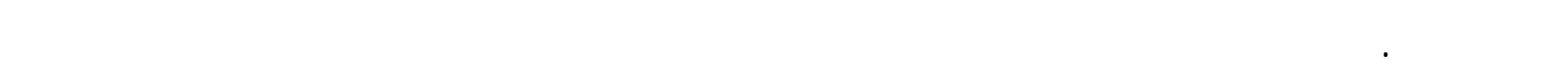

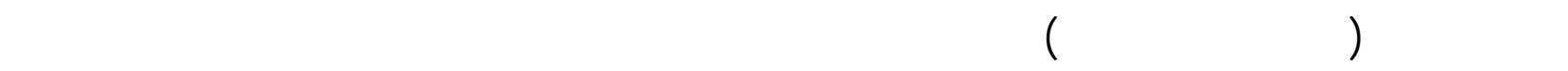

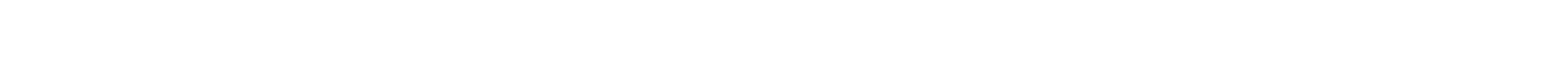

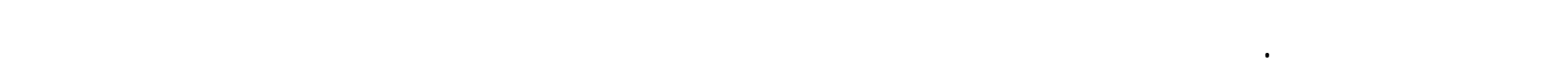

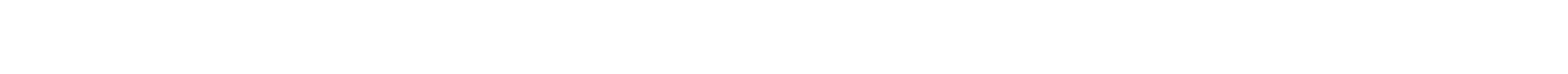
الهيدروكيميائية ( التصريف.

\section{INTRODUCTION}

The quality of groundwater is as important as its quantity, for the suitability of water for various purposes. Water quality analysis is an important issue in groundwater studies. Variation in groundwater quality in an area is a function of physical and chemical parameters that are greatly influenced by geological formations and anthropogenic activities (Subramani et al., 2005). Sinjar city and all villages in study area depend on ground water for supply via wells and springs.

The objective of this study is the evaluation of ground water quality, this helps both in present water resource planning as well as provide baseline for future water quality evolution studies,and examine the spatial distribution of chemical parameters for delineation of various status categories of ground water quality. The study area is part of North Sinjar plain, extended N-W Iraq, and is at a distance of about $135 \mathrm{~km}$ to the North West of Mosul city, between longitude ( $41^{\circ} 42^{\prime} 12^{\prime \prime}$ ) ( $42^{\circ} 05^{\prime} 06^{\prime \prime}$ ) East and latitude

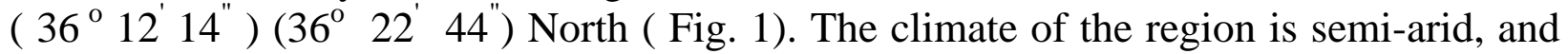
according to the meteorological station in Sinjar during the last forty years the mean annual precipitation and evaporation rate are $380 \mathrm{~mm} / \mathrm{yr}$ and $270 \mathrm{~mm} / \mathrm{yr}$ (class A) respectively, (Meteorological Station in Sinjar, 2003) generally the precipitation occurs between October and May.

\section{METHODOLOGY}

Ground water samples were collected from fourteen deep wells, which covers the study area during March 2007 (Fig. 1). Water samples were collected in 1 liter clean plastic bottles after ten minute of pumpage, at the time of sampling, sampling bottles were thoroughly rinsed 2-3 times using the ground water to be sampled, this was done to ensure the removal of ground water stored in well pipes to obtain a representative samples. The $(\mathrm{pH})$ and electrical conductivity (EC) were measured using $(\mathrm{pH})$ and conductivity meters in the field. Total dissolved solids (TDS) were measured by evaporation method (APHA, 1975) calcium $\left(\mathrm{Ca}^{++}\right)$and magnesium $\left(\mathrm{Mg}^{++}\right)$were analysed by titration using EDTA (Jenkins et al., 1980). 


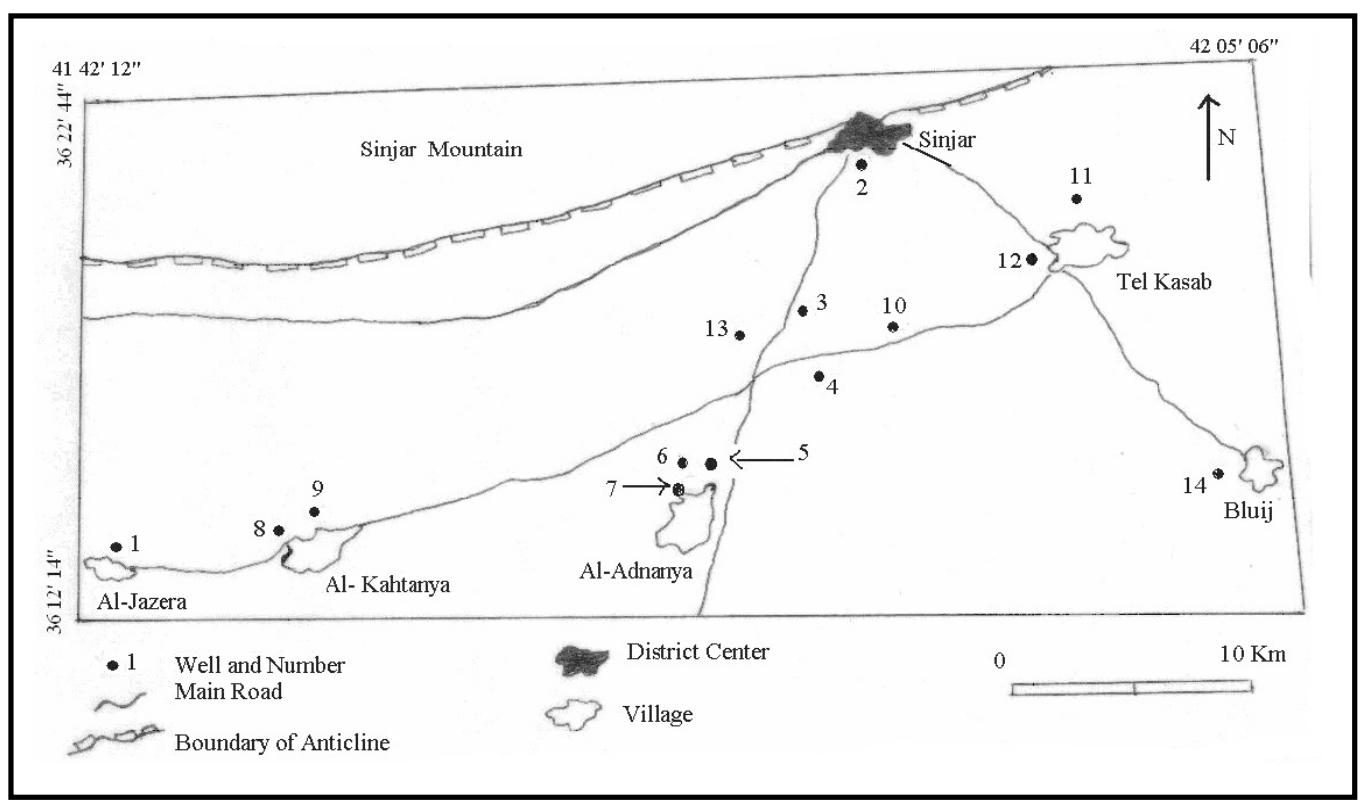

Fig. 1: Map showing the water sampling locations of Al-Adnanya-Sinjar area.

sodium $\left(\mathrm{Na}^{+}\right)$and potassium $\left(\mathrm{K}^{+}\right)$were determined by flamephometer (Vogel, 1961). Total hardness (TH) was calculated using the formula given by (Sawyer et al., 1967).

$\mathrm{TH}\left(\right.$ as $\left.\mathrm{mg} \mathrm{CaCO}_{3} / \mathrm{l}\right)=(\mathrm{Ca}+\mathrm{Mg}) \mathrm{meq} / \mathrm{l} \times 50$

Sulphate $\left(\mathrm{SO}_{4}{ }^{-2}\right)$ were estimated by colorimetric techniques using spectrophotometer (Vogel, 1961). Bicarbonate $\left(\mathrm{HCO}_{3}{ }^{-}\right)$were analysed by titration using $0.02 \mathrm{~N}\left(\mathrm{H}_{2} \mathrm{SO}_{4}\right)$, and chloride $\left(\mathrm{Cl}^{-}\right)$was determined by titration using $0.05 \mathrm{~N}\left(\mathrm{AgNO}_{3}\right)$ (Vogel, 1961). All concentration are expressed in milligram per liter $(\mathrm{mg} / \mathrm{l})$ except $(\mathrm{pH})$ and $(\mathrm{EC})$. Each sample was checked for accuracy by calculating their percent charge balance errors (\% CBE). No sample in the database have a (\% CBE) greater than $5.1 \%$ see (Table 1 ), which ensures the reliability of the chemical data. All these analysis were carried out in soil department lab. except sulphate which were analysed in the chemistry lab. of agriculture college.

\section{GEOLOGICAL AND HYDROGEOLOGICAL SETTING}

The study area is part of Al-Jazera region which extends from the Tigris and Tharthar valley in the NE and SE, Sinjar mountain in the N, the Der-Alzor depression in the W up to the Euphrates in the SW (Jassim and Goff, 2006). The geological sequence in the study area extends from Shiranish Formation which is the oldest formation cropping out in Sinjar Anticline to the Quaternary deposits which are covering most of the study area, (Fig. 2). Al-Fatha Formation is divided into two members, the lower member consists of green marl, limestone and gypsum while the upper member consists of red clay, marl, limestone, silt and gypsum (Buday, 1980).The Injana Formation which is exposed in some locations as small lenses and some hills which consist of sandstone, siltstone and claystone, covers most of the study area except the quaternary deposits 
(Buday, 1980). Quaternary deposits consist of sandy and loamy soil, local gypsiferous, rock fragment, conglomerate with lenses of sand, silt and rare clay (Buday, 1980).

From hydrogeological point of view, three main aquifers exist in the study area, there are Quaternary aquifer, Injana aquifer and Al-Fatha aquifer (Awad, 1984). The main aquifer is the Injana sandstone aquifer due to its high permeability and its great thickness. All the studied wells penetrate this aquifer except Bluij well $\mathrm{w}_{14}$ by which it penetrates Al-Fatha aquifer (Fig. 3). Injana aquifer has been considered as unconfined aquifer except in some locations it becomes semi-confined aquifer, due to the presence of a lenticular shape clay beds overlying the aquifer. The hydraulic properties of the well located $5 \mathrm{~km}$ North Bluij village which penetrates Injana aquifer have transmissivity of $25.2 \mathrm{~m}^{2} /$ day, specific yield $1.63 \times 10^{-4}$ and hydraulic conductivity $0.16 \mathrm{~m} /$ day. The ground water in this well is convenient for drinking, domestic and irrigation purposes (Awad, 1984). The second aquifer is the Al-Fatha Aquifer which consists of beds of gypsum, marl and thin limestone, only gypsum beds act as an aquifer because they have been extensively karastified leading to high concentration of sulphate due to dissolution of gypsum (Jassim and Goff, 2006) which were observed in Bluij well $\mathrm{w}_{14}$. The Quaternary aquifer considered as the minor aquifer, and the shallow wells penetrates this aquifer, with depth doesn't exceed 25 meter below the land surface (Awad, 1984). The recharge of the study area is accomplished through direct vertical percolation of rainfall, and vertical seepage from wadies with ephemeral water flow.

\section{GROUND WATER TYPES:}

A summary of the result of chemical analysis of ground water samples collected from 14 wells from the study area was presented in (Table 1). The major cation and anion were plotted on piper diagram (Piper, 1944) after converting the concentration from mg/l to meq\% Two types of water were recognized in the studied area, first is bicarbonate type $\left(\mathrm{Ca}-\mathrm{HCO}_{3}\right)$, second is sulphate type which includes two sub groups $\left(\mathrm{CaSO}_{4}\right)$ and $\left(\mathrm{MgSO}_{4}\right)$. First, bicarbonate ground water types (total samples $\left.=4\right)$, TDS ranges between (358 - $615 \mathrm{mg} / \mathrm{l}$ ) while the EC and TH range between $(471-864 \mu \mathrm{mohs} / \mathrm{cm})$ and $(180-332$ $\mathrm{mg} / \mathrm{l})$ respectively. $\mathrm{HCO}_{3}^{-}$is the dominant anion $(174.2-238.4 \mathrm{mg} / \mathrm{l})$, followed by $\mathrm{SO}_{4}^{-2}$ (45.6 - $129.4 \mathrm{mg} / \mathrm{l})$, and $\mathrm{Cl}^{-}(27.9-56.6 \mathrm{mg} / \mathrm{l})$, the $\mathrm{Ca}^{++}$is the dominant cation (38.7 - $94.3 \mathrm{mg} / \mathrm{l})$ followed by $\mathrm{Mg}^{++}(20.3-30.4 \mathrm{mg} / \mathrm{l}), \mathrm{Na}^{+}(18.5-39.2 \mathrm{mg} / \mathrm{l})$ and $\mathrm{k}^{+}$ (3.4 - $6.1 \mathrm{mg} / \mathrm{l}$ ). The bicarbonate in ground water could be derived from $\mathrm{CO}_{2}$ in the atmosphere, and its presence in the soil zone which combines with rain water to form carbonic acid and then bicarbonate as explained below:

$\mathrm{CO}_{2}+\mathrm{H}_{2} \mathrm{O}=\mathrm{H}_{2} \mathrm{CO}_{3}$

$\mathrm{H}_{2} \mathrm{CO}_{3}=\mathrm{H}^{+}+\mathrm{HCO}_{3}^{-}$

The $\mathrm{HCO}_{3}^{-}$may also be derived from the dissolution of silicate mineral, feldspar and plagioclase. A general reaction for the weathering of silicate mineral rocks with carbonic acid is as follow

Cations (silicates) $+\mathrm{H}_{2} \mathrm{CO}_{3}=\mathrm{H}_{4} \mathrm{SiO}_{4}+\mathrm{HCO}_{3}^{-}+$Cations + solid products (mostly clay). (Davis and Dewiest, 1966). 


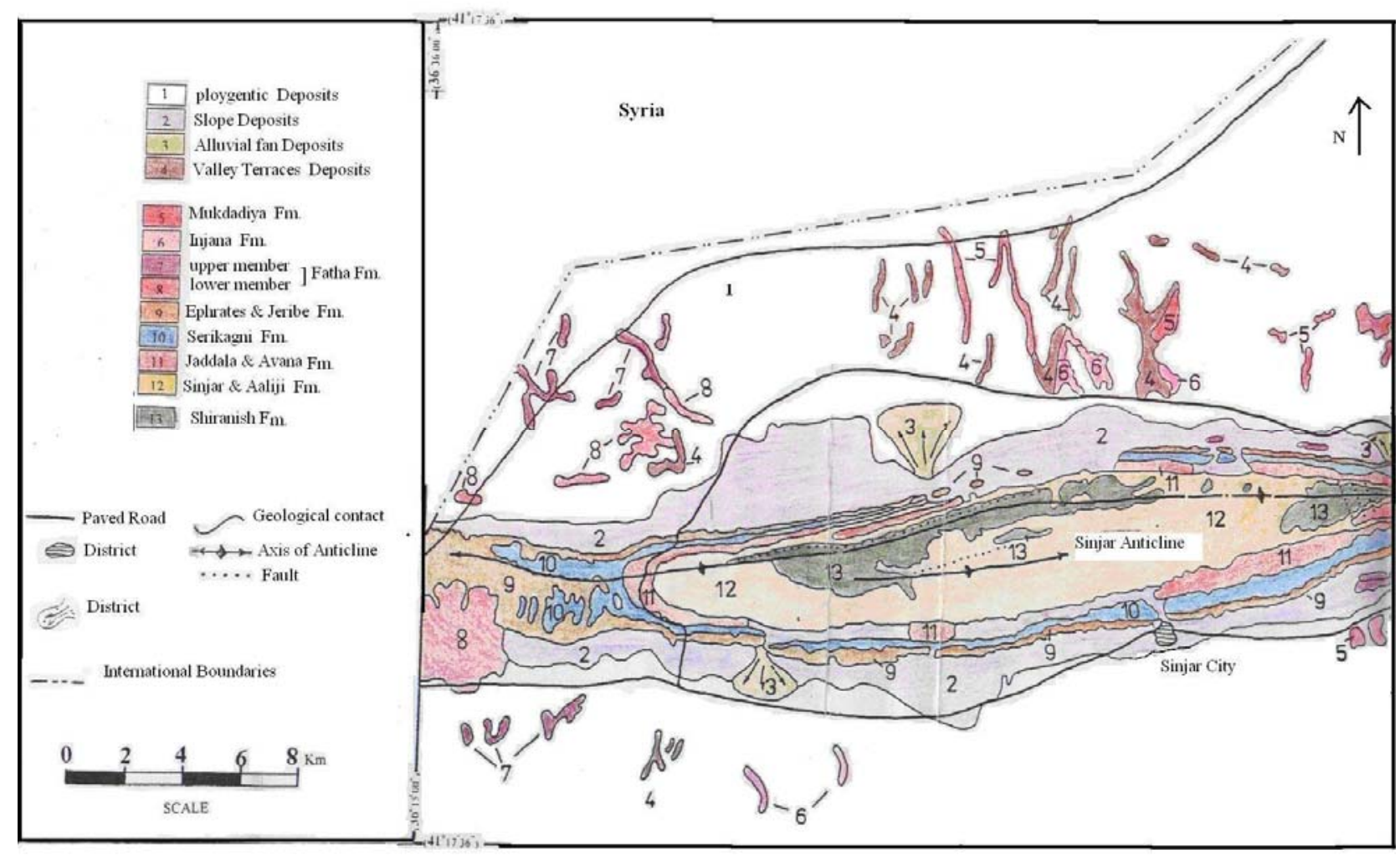

Fig. 2: Geological map of the study area and surrounded area (GEOSURV, 1996).

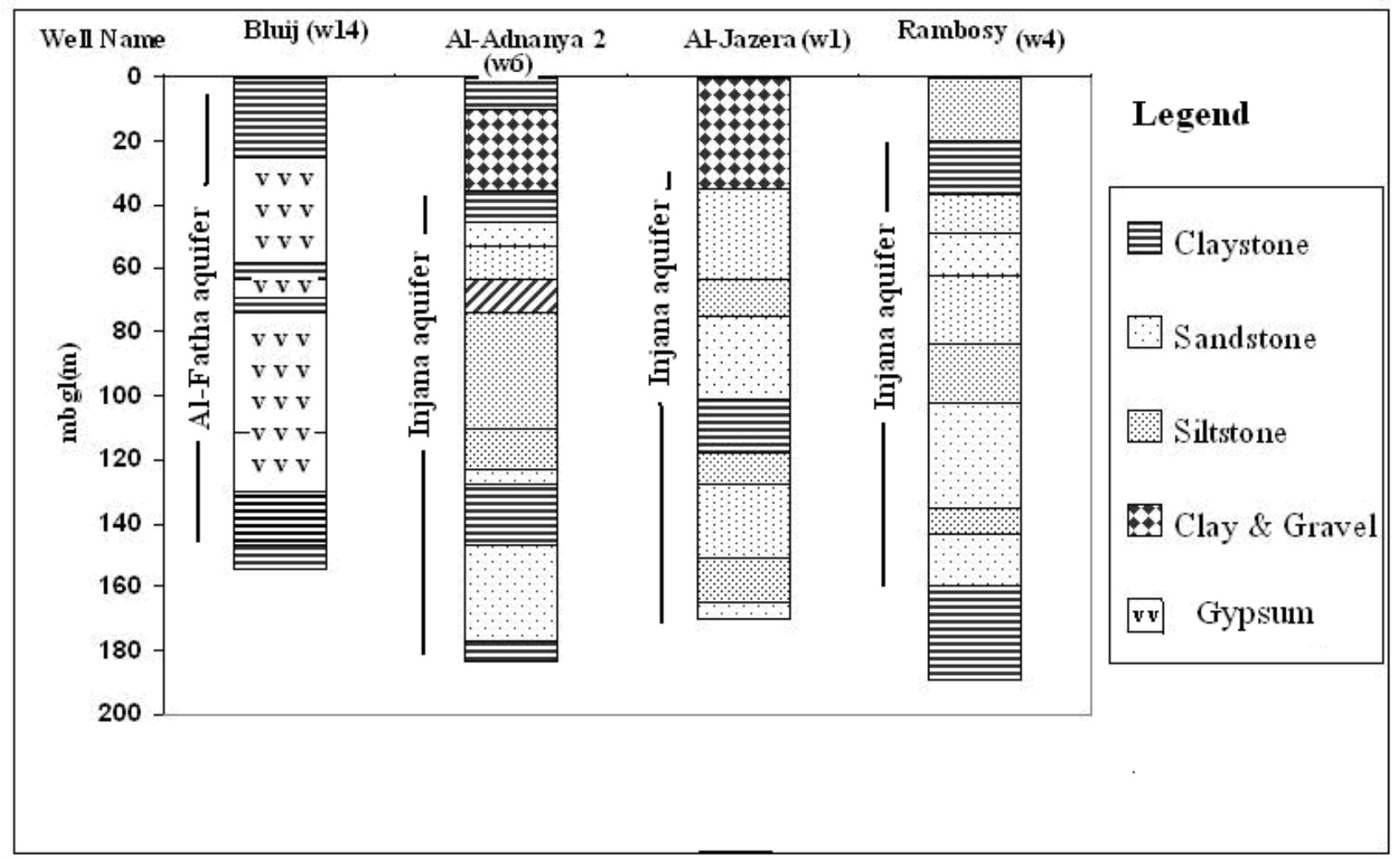

Fig. 3: Lithology section of selected wells in the study area after (GDWN, 2005). 
Second, Sulphate water types (total samples $=10$ ) TDS ranges between (661 - $3112 \mathrm{mg} / \mathrm{l})$ while the EC and TH range between (1042 - $4077 \mu \mathrm{mohs} / \mathrm{cm}$ ) and (374 - $2192 \mathrm{mg} / \mathrm{l}$ ) respectively. The $\mathrm{SO}_{4}{ }^{-2}$ is the dominate ion $(195.2-1418 \mathrm{mg} / \mathrm{l})$, while the concentration of $\mathrm{HCO}_{3}{ }^{-}$and $\mathrm{Cl}^{-}$vary from $(180.5$ - $316.2 \mathrm{mg} / \mathrm{l})$ and $(46.3-390.6 \mathrm{mg} / \mathrm{l})$ respectively. $\mathrm{Ca}^{++}$is the dominant Cation except in wells $\mathrm{w}_{7}$ and $\mathrm{w}_{11}$ where $\mathrm{Mg}^{++}$is the dominant ion.

The concentration of $\mathrm{Ca}^{++}, \mathrm{Mg}^{++}, \mathrm{Na}^{+}$and $\mathrm{K}^{+}$ranges between $(81.3-440.6 \mathrm{mg} / \mathrm{l})$, (41.6 - $256.6 \mathrm{mg} / \mathrm{l}),(19.3$ - $146.3 \mathrm{mg} / \mathrm{l})$ and (4.1-14.2 $\mathrm{mg} / \mathrm{l})$ respectively. The sources of calcium and sulphate in the water comes from calcite cement in Injana formation and gypsum which is found as secondary gypsum in quaternary deposits and soil. Magnesium may come from the dissolution of Mg rich minerals such as Mg-calcite. The anomalously high concentration of ions of water in well Bluij $\left(\mathrm{w}_{14}\right)$ compared with the other wells is due to the dissolution of gypsum rocks of Al-Fatha aquifer.

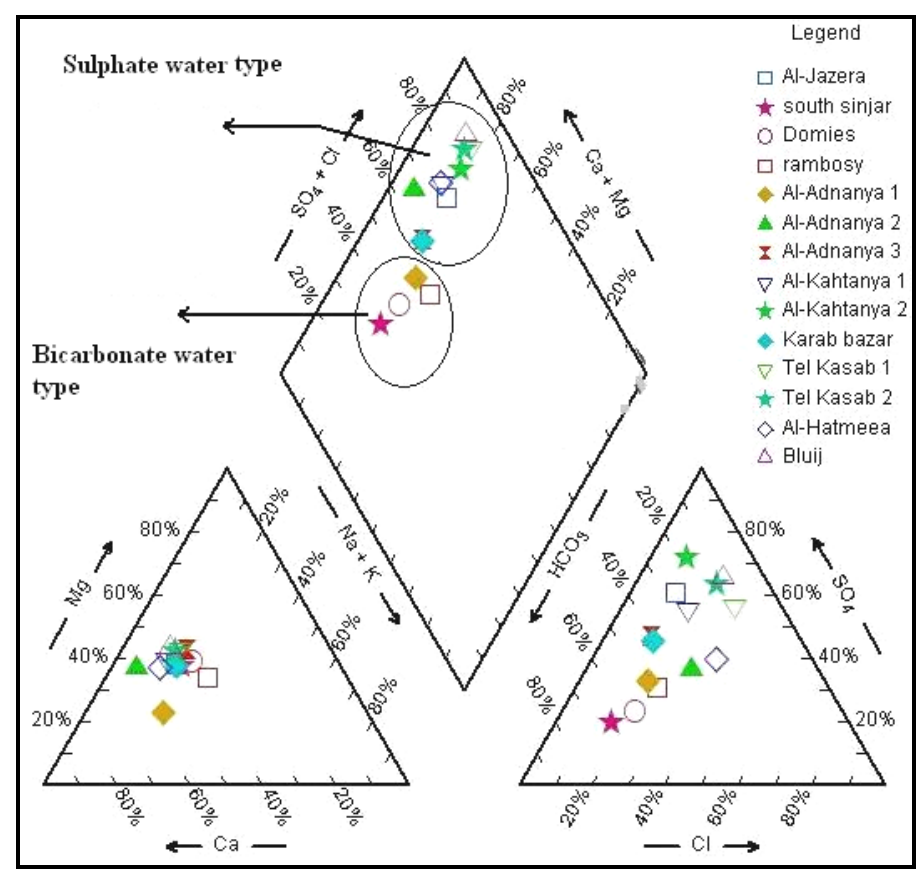

Fig. 4: Piper diagram showing the distribution of major cation, anion and chemical types of ground water in the study area.

\section{STATISTICAL TREATMENT OF DATA}

Cluster analysis has been useful in studying the similar pair groups of chemical constituents of water. The values of chemical constituents were subjected to hierarchical cluster analysis (HCA). Based on the indicies of correlation coefficients, similar pair groups of chemical constituents have been linked and then the next most similar pair groups and so on, until all the chemical constituents have been clustered in a dendrogram by averaging method (Davis, 1973). Also these methods were applied by (Eriksson, 1985) and (Sarkar et al., 2007). A 10x10 matrix of correlation coefficients was computed to perform cluster analysis. Correlation matrices of various stages of clustering are given in tables 2 to 10. In the first step of cluster analysis high correlation coefficients were identified from initial linear correlation matrix, highest correlation between TDS and TH (Table 2). 
Which can be combined into one column labeled TDS-TH (Table 3) simply by arithmetic averaging method (Davis, 1973). The new matrix highest correlation TDS-TH with $\mathrm{Mg}^{++}$were clustered (Table 4), the next step TDS-TH-Mg combined with EC cluster recalculated (Table 5). In the subsequent step $\mathrm{SO}_{4}^{-2}$ was clustered with TDS-TH-Mg -EC (Table 6). Then $\mathrm{Ca}^{++}$was clustered with TDS-TH-Mg -EC- $\mathrm{SO}_{4}$ (Table 7). Next correlation $\mathrm{Na}$ was combined with TDS-TH-Mg -EC- $\mathrm{SO}_{4}$-Ca (Table 8). K clustered with TDS-TH-Mg -EC- $\mathrm{SO}_{4}$-Ca-Na (Table 9) then $\mathrm{Cl}$ and TDS-TH-EC-Ca- Mg- $\mathrm{SO}_{4}$ $\mathrm{Na}-\mathrm{K}$ were clustered. Finally the two cluster TDS-TH-EC-Ca- Mg- $\mathrm{SO}_{4}-\mathrm{Na}-\mathrm{K}-\mathrm{Cl}$ and $\mathrm{HCO}_{3}$ were linked (Table10) the resulting dendrogram for ground water is shown in (Fig. 5). The result of cluster analysis indicate two board types of ground water in the study area.

Type I: TDS-TH-EC-Ca- Mg- $\mathrm{SO}_{4}-\mathrm{Na}-\mathrm{K}-\mathrm{Cl}$

Type II: $\mathrm{HCO}_{3}^{-}$

This result agrees with the chemical classification by which two groups of water were found

Table 2: Correlation matrix of first stage for ground water.

\begin{tabular}{|c|c|c|c|c|c|c|c|c|c|c|}
\hline & $\mathrm{EC}$ & TDS & $\mathrm{TH}$ & $\mathrm{Ca}^{++}$ & $\mathrm{Mg}^{++}$ & $\mathrm{Na}^{+}$ & $\mathrm{K}^{+}$ & $\mathrm{Cl}^{-}$ & $\mathrm{SO}_{4}^{-2}$ & $\mathrm{HCO}_{3}$ \\
\hline EC & 1 & & & & & & & & & \\
\hline TDS & 0.982 & 1 & & & & & & & & \\
\hline $\mathrm{TH}$ & 0.965 & 0.986 & 1 & & & & & & & \\
\hline $\mathrm{Ca}^{++}$ & 0.920 & 0.940 & 0.970 & 1 & & & & & & \\
\hline $\mathrm{Mg}^{++}$ & 0.953 & 0.976 & 0.971 & 0.885 & 1 & & & & & \\
\hline $\mathrm{Na}^{+}$ & 0.756 & 0.802 & 0.717 & 0.618 & 0.775 & 1 & & & & \\
\hline $\mathrm{K}^{+}$ & 0.492 & 0.569 & 0.546 & 0.527 & 0.529 & 0.628 & 1 & & & \\
\hline $\mathrm{Cl}^{-}$ & 0.751 & 0.682 & 0.669 & 0.653 & 0.646 & 0.353 & 0.121 & 1 & & \\
\hline $\mathrm{SO}_{4}^{-2}$ & 0.932 & 0.955 & 0.928 & 0.863 & 0.942 & 0.869 & 0.644 & 0.536 & 1 & \\
\hline $\mathrm{HCO}_{3}{ }^{-}$ & -0.320 & -0.247 & -0.192 & -0.132 & -0.243 & -0.327 & -0.097 & -0.361 & -0.419 & 1 \\
\hline
\end{tabular}

Table 3: Correlation matrix of second stage for ground water.

\begin{tabular}{|l|c|c|c|c|c|c|c|c|c|}
\hline & EC & TDS-TH & $\mathrm{Ca}^{++}$ & $\mathrm{Mg}^{++}$ & $\mathrm{Na}^{+}$ & $\mathrm{K}^{+}$ & $\mathrm{Cl}^{-}$ & $\mathrm{SO}_{4}{ }^{-2}$ & $\mathrm{HCO}_{3}{ }^{-}$ \\
\hline EC & 1 & & & & & & & & \\
\hline TDS-TH & $\mathbf{0 . 9 7 3}$ & 1 & & & & & & & \\
\hline $\mathrm{Ca}^{++}$ & 0.920 & 0.955 & 1 & & & & & & \\
\hline $\mathrm{Mg}^{++}$ & 0.953 & 0.974 & 0.885 & 1 & & & & & \\
\hline $\mathrm{Na}^{+}$ & 0.756 & 0.759 & 0.681 & 0.775 & 1 & & & & \\
\hline $\mathrm{K}^{+}$ & 0.492 & 0.557 & 0.527 & 0.529 & 0.628 & 1 & & & \\
\hline $\mathrm{Cl}^{-}$ & 0.751 & 0.675 & 0.653 & 0.646 & 0.353 & 0.121 & 1 & & \\
\hline $\mathrm{SO}_{4}^{-2}$ & 0.932 & 0.941 & 0.863 & 0.942 & 0.869 & 0.644 & 0.536 & 1 & \\
\hline $\mathrm{HCO}_{3}^{-}$ & -0.320 & -0.219 & -0.132 & -0.243 & -0.327 & -0.097 & -0.361 & -0.419 & 1 \\
\hline
\end{tabular}


Table 4: Correlation matrix of third stage for ground water.

\begin{tabular}{|c|c|c|c|c|c|c|c|c|}
\hline & Ec & TDS-TH-Mg & $\mathrm{Ca}^{++}$ & $\mathrm{Na}^{+}$ & $\mathrm{K}^{+}$ & $\mathrm{Cl}^{-}$ & $\mathrm{SO}_{4}^{-2}$ & $\mathrm{HCO}_{3}^{-}$ \\
\hline $\mathrm{EC}$ & 1 & & & & & & & \\
\hline TDS-TH-Mg & $\mathbf{0 . 9 6 3}$ & 1 & & & & & & \\
\hline $\mathrm{Ca}^{++}$ & 0.920 & 0.920 & 1 & & & & & \\
\hline $\mathrm{Na}^{+}$ & 0.756 & 0.767 & 0.681 & 1 & & & & \\
\hline $\mathrm{K}^{+}$ & 0.492 & 0.543 & 0.527 & 0.628 & 1 & & & \\
\hline $\mathrm{Cl}^{-}$ & 0.751 & 0.660 & 0.653 & 0.353 & 0.121 & 1 & & \\
\hline $\mathrm{SO}_{4}^{-2}$ & 0.932 & 0.941 & 0.863 & 0.869 & 0.644 & 0.536 & 1 & \\
\hline $\mathrm{HCO}_{3}^{-}$ & -0.320 & -0.231 & -0.132 & - & - & - & - & 1 \\
& & & & 0.327 & 0.097 & 0.361 & 0.419 & \\
\hline
\end{tabular}

Table 5: Correlation matrix of fourth stage for ground water.

\begin{tabular}{|c|c|c|c|c|c|c|c|}
\hline & TDS-TH-Mg-EC & $\mathrm{Ca}^{++}$ & $\mathrm{Na}^{+}$ & $\mathrm{K}^{+}$ & $\mathrm{Cl}^{-}$ & $\mathrm{SO}_{4}^{-2}$ & $\mathrm{HCO}_{3}{ }^{-}$ \\
\hline $\begin{array}{c}\text { TDS-TH- } \\
\mathrm{Mg} \text {-EC }\end{array}$ & 1 & & & & & & \\
\hline $\mathrm{Ca}^{++}$ & 0.920 & 1 & & & & & \\
\hline $\mathrm{Na}^{+}$ & 0.761 & 0.681 & 1 & & & & \\
\hline $\mathrm{K}^{+}$ & 0.517 & 0.527 & 0.628 & 1 & & & \\
\hline $\mathrm{Cl}^{-}$ & 0.705 & 0.653 & 0.353 & 0.121 & 1 & & \\
\hline $\mathrm{SO}_{4}^{-2}$ & $\mathbf{0 . 9 3 6}$ & 0.863 & 0.869 & 0.644 & 0.536 & 1 & \\
\hline $\mathrm{HCO}_{3}^{-}$ & -0.275 & -0.132 & -0.327 & -0.097 & -0.361 & -0.419 & 1 \\
\hline
\end{tabular}

Table 6: Correlation matrix of fifth stage for ground water.

\begin{tabular}{|c|c|c|c|c|c|c|}
\hline & TDS-TH-Mg-EC- SO & $\mathrm{Ca}^{++}$ & $\mathrm{Na}^{+}$ & $\mathrm{K}^{+}$ & $\mathrm{Cl}^{-}$ & $\mathrm{HCO}_{3}{ }^{-}$ \\
\hline TDS-TH-EC-Ca & 1 & & & & & \\
\hline $\mathrm{Ca}^{++}$ & $\mathbf{0 . 8 9 1}$ & 1 & & & & \\
\hline $\mathrm{Na}^{+}$ & 0.815 & 0.681 & 1 & & & \\
\hline $\mathrm{K}^{+}$ & 0.580 & 0.527 & 0.628 & 1 & & \\
\hline $\mathrm{Cl}^{-}$ & 0.620 & 0.653 & 0.353 & 0.121 & 1 & \\
\hline $\mathrm{HCO}_{3}^{-}$ & -0.347 & -0.132 & -0.327 & -0.097 & -0.361 & 1 \\
\hline
\end{tabular}

Table 7: Correlation matrix of sixth stage for ground water.

\begin{tabular}{|c|c|c|c|c|c|}
\hline & TDS-TH-Mg-EC- $\mathrm{SO}_{4}^{-} \mathrm{Ca}$ & $\mathrm{Na}^{+}$ & $\mathrm{K}^{+}$ & $\mathrm{Cl}^{-}$ & $\mathrm{HCO}_{3}{ }^{-}$ \\
\hline TDS-TH-Mg-EC- $\mathrm{SO}_{4}-\mathrm{Ca}$ & 1 & & & & \\
\hline $\mathrm{Na}^{+}$ & $\mathbf{0 . 7 1 6}$ & 1 & & & \\
\hline $\mathrm{K}^{+}$ & 0.553 & 0.628 & 1 & & \\
\hline $\mathrm{Cl}^{-}$ & 0.636 & 0.353 & 0.121 & 1 & \\
\hline $\mathrm{HCO}_{3}{ }^{-}$ & -0.239 & -0.327 & -0.097 & -0.361 & 1 \\
\hline
\end{tabular}

Table 8: Correlation matrix of seventh stage for ground water.

\begin{tabular}{|c|c|c|c|c|}
\hline & TDS-TH-Mg -EC- $\mathrm{SO}_{4}-\mathrm{Ca}-\mathrm{Na}$ & $\mathrm{K}^{+}$ & $\mathrm{Cl}^{-}$ & $\mathrm{HCO}_{3}{ }^{-}$ \\
\hline TDS-TH-Mg-EC- SO & \\
\hline & 1 & & & \\
\hline $\mathrm{K}^{+}$ & $\mathbf{0 . 5 9 0}$ & 1 & & \\
\hline $\mathrm{Cl}^{-}$ & 0.494 & 0.121 & 1 & \\
\hline $\mathrm{HCO}_{3}^{-}$ & -0.283 & -0.097 & -0.361 & 1 \\
\hline
\end{tabular}


Table 9: Correlation matrix of Eighth stage for ground water.

\begin{tabular}{|c|c|c|c|}
\hline & TDS-TH-EC-Ca- $\mathrm{Mg}$ - $\mathrm{SO}_{4}-\mathrm{Na}-\mathrm{K}$ & $\mathrm{Cl}^{-}$ & $\mathrm{HCO}_{3}{ }^{-}$ \\
\hline TDS-TH-EC-Ca- Mg- $\mathrm{SO}_{4}-\mathrm{Na}-\mathrm{K}$ & 1 & & \\
\hline $\mathrm{Cl}^{-}$ & $\mathbf{0 . 3 0 7}$ & 1 & \\
\hline $\mathrm{HCO}_{3}{ }^{-}$ & -0.190 & -0.361 & 1 \\
\hline
\end{tabular}

Table 10: Correlation matrix of final stage for ground water.

\begin{tabular}{|c|c|c|}
\hline & TDS-TH-EC-Ca- $\mathrm{Mg}-\mathrm{SO}_{4}-\mathrm{Na}-\mathrm{K}-\mathrm{Cl}$ & $\mathrm{HCO}_{3}{ }^{-}$ \\
\hline TDS-TH-EC-Ca- Mg- $\mathrm{SO}_{4}-\mathrm{Na}-\mathrm{K}-\mathrm{Cl}$ & 1 & \\
\hline $\mathrm{HCO}_{3}{ }^{-}$ & -0.275 & 1 \\
\hline
\end{tabular}

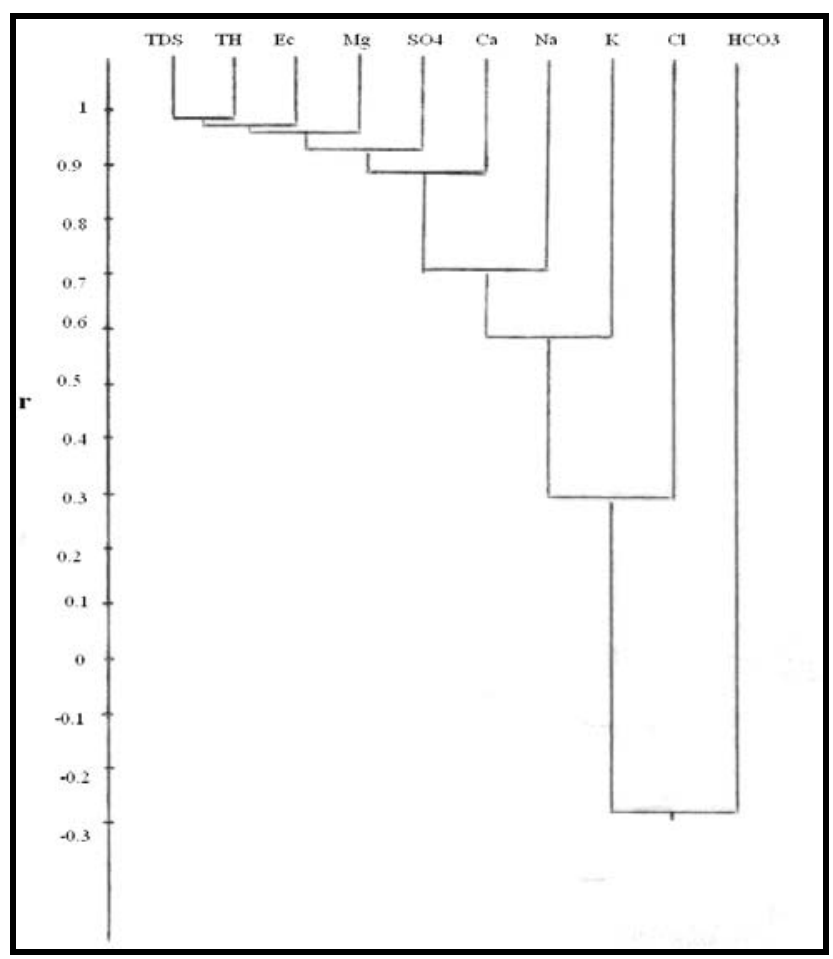

Fig. 5: Dendrogram for cluster analysis of ground water of the study area.

\section{GROUND WATER QUALITY MAPPING}

Ground water quality gives a clear picture about the usability of the ground water for different purpose. To foresee the suitability of ground water for drinking purpose, each sample was compared with (WHO, 1983) guidelines for drinking; it gives the desirable and maximum allowable limits for the presence of various parameters in ground water (Table 11). Spatial distribution maps of concentration TDS, TH, $\mathrm{Ca}^{++}, \mathrm{Mg}^{++}$and $\mathrm{SO}_{4}^{-2}$ were drawn. Some values of these samples exceeds the desirable limits for drinking. All ground water samples used for mapping of water quality are from Injana aquifer. Sample $\mathrm{w}_{14}$ Bluij well is not used because its water comes from Al-Fatha aquifer.

The spatial distribution of $\mathrm{Ca}^{++}$and $\mathrm{Mg}^{++}$(Figs. 6 and 7) illustrates that the wells under study occurring in sinjar, Domies and Rambosy falls under most desirable limit for drinking, while the rest of the wells doesn't exceeds the maximum allowable limit.

The spatial distribution of TDS (Fig. 8) showes that the wells located in Telkasab and Al-Kahtanya 2 falls under brackish water (TDS $>1000$ ) while the rest of wells occurs under fresh water type (TDS<1000). The spatial distribution of TH (Fig. 9) showes that 
wells occurring in Telkasab, Al-Jazera and Al-Kahtanya exceeds the maximum allowable limit while the remaining wells fall within the acceptable limit.

The spatial distribution of $\mathrm{SO}_{4}^{-2}$ (Fig.10) shows that the wells under study occurring in Telkasab and Al-Kahtanya 2 exceeds the maximum allowable limit. While the rest of the wells are below maximum allowable limit for drinking.

Final map is a pictorial representation of ground water quality for drinking production from integration the previous maps to delineate the location of desirable, maximum permissible and unsuitable for drinking (Fig. 11).

Water quality map for Injana aquifer shows that the wells occurring in Sinjar, Domies and Rambosy fall under desirable for drinking category, while the wells were occurring in Al-Adnanya and Al-Jazera falls below the maximum permissible limit for drinking category, and the wells occurring in Telkasab and Al-Kahtanya falls under unsuitable for drinking category.

Table 11: Permissible limits prescribed by (WHO, 1983) for drinking.

\begin{tabular}{|c|c|c|}
\hline Parameters & Most desirable limits & Maximum allowable limits \\
\hline $\mathrm{pH}$ & $7-8.5$ & 9.2 \\
\hline $\mathrm{TDS}(\mathrm{mg} / \mathrm{l})$ & 500 & 1500 \\
\hline $\mathrm{TH}(\mathrm{mg} / \mathrm{l})$ & 100 & 500 \\
\hline $\mathrm{Na}^{+}(\mathrm{mg} / \mathrm{l})$ & --- & 200 \\
\hline $\mathrm{Ca}^{++}(\mathrm{mg} / \mathrm{l})$ & 75 & 200 \\
\hline $\mathrm{Mg}^{++}(\mathrm{mg} / \mathrm{l})$ & 50 & 150 \\
\hline $\mathrm{Cl}^{-}(\mathrm{mg} / \mathrm{l})$ & 200 & 600 \\
\hline $\mathrm{SO}_{4}^{-2}(\mathrm{mg} / \mathrm{l})$ & 200 & 400 \\
\hline $\mathrm{NO}_{3}{ }^{-}(\mathrm{mg} / \mathrm{l})$ & 45 & ---- \\
\hline
\end{tabular}

Relatively high concentrations of major cations, anions and TDS in Telkasab and Al-Kahtanya may be due to the very slow flowing of water owing to the gentle slope of geological layers and the long residence of water in aquifer. Also the dry condition created by long periods of discontinuous raining causes the increased concentration of ions in ground water.

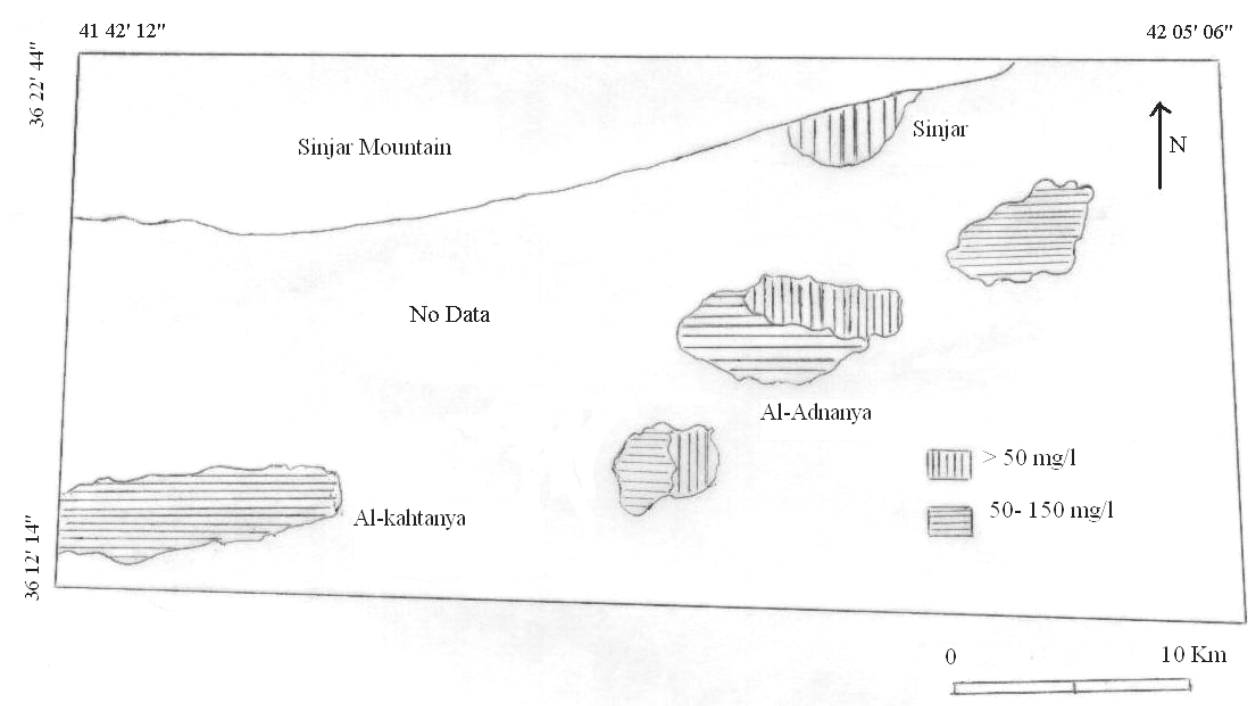

Fig. 6: Distribution of calcium $\left(\mathrm{Ca}^{++}\right)$in Injana aquifer. 


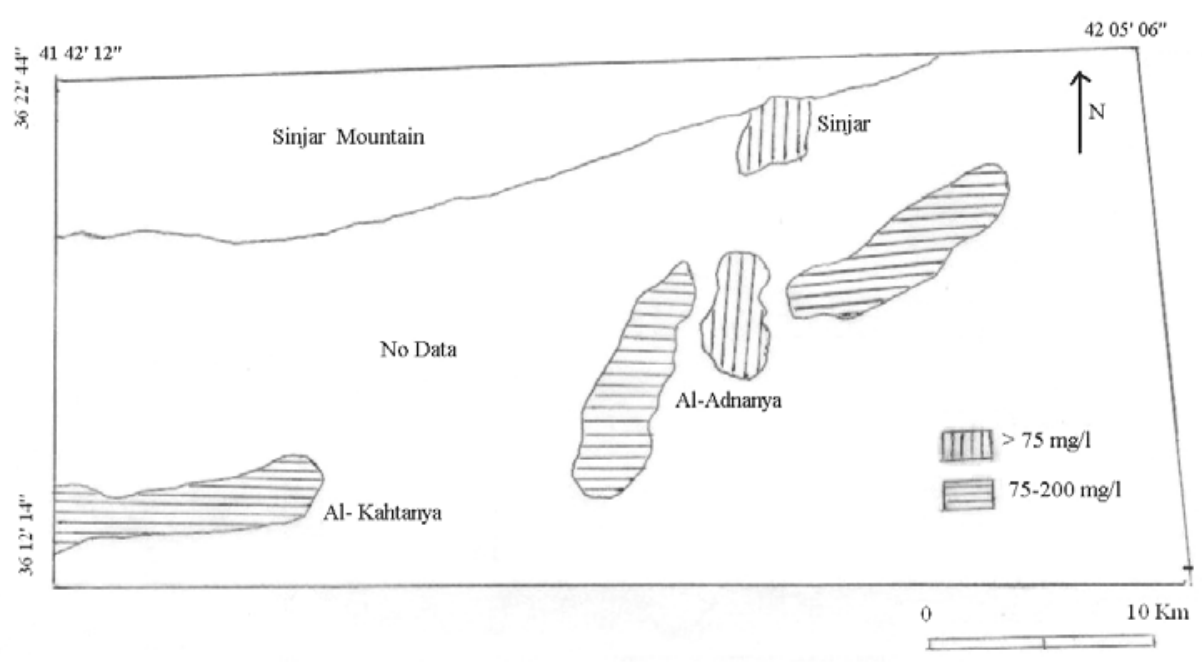

Fig. 7: Distribution of magnesium $\left(\mathrm{Mg}^{++}\right)$in Injana aquifer.

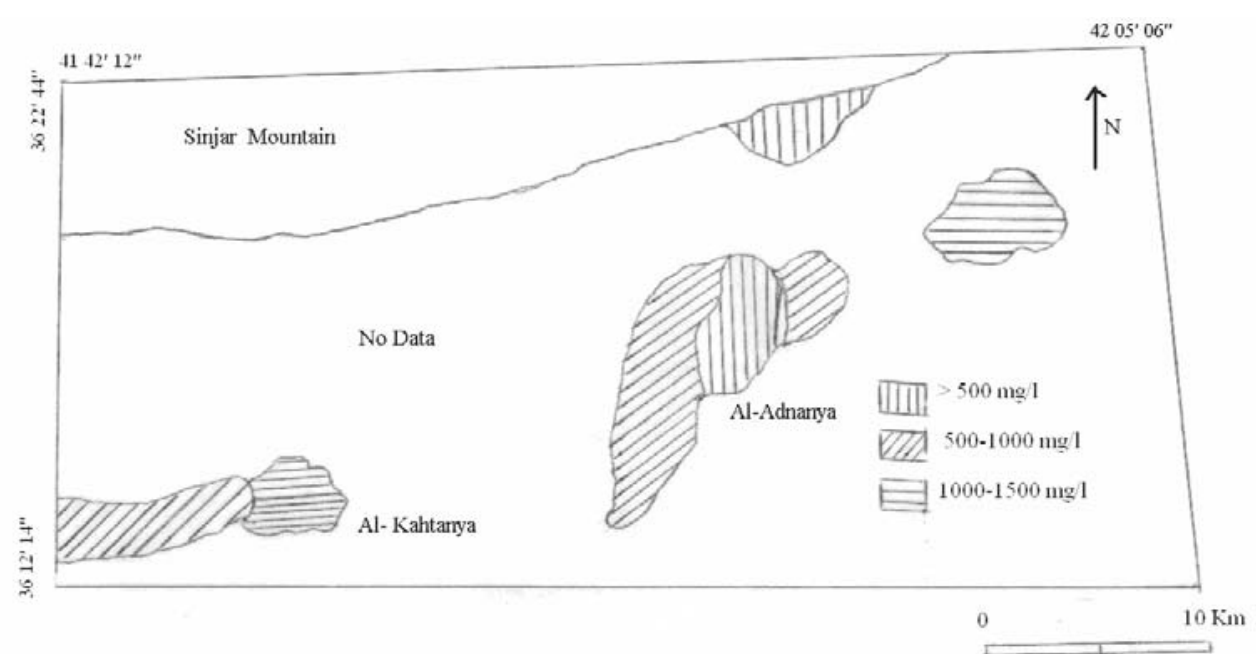

Fig. 8: Distribution of total dissolved solid (TDS) in Injana aquifer.

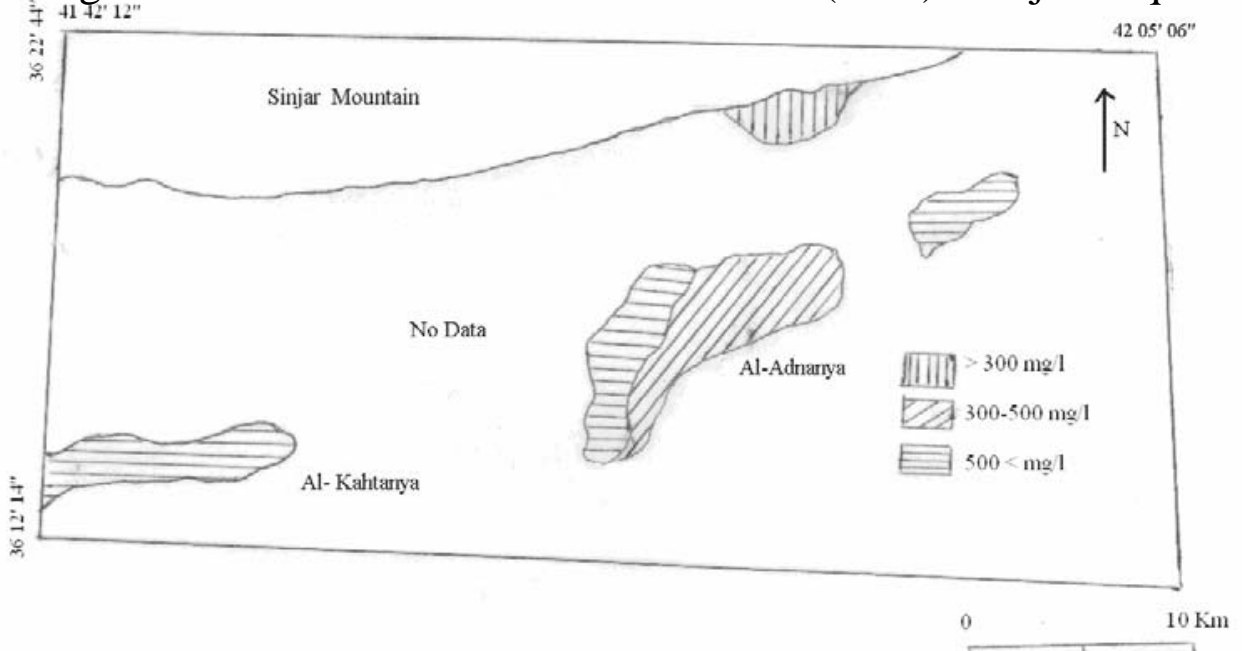

Fig. 9: Distribution of total hardness (TH) in Injana aquifer. 


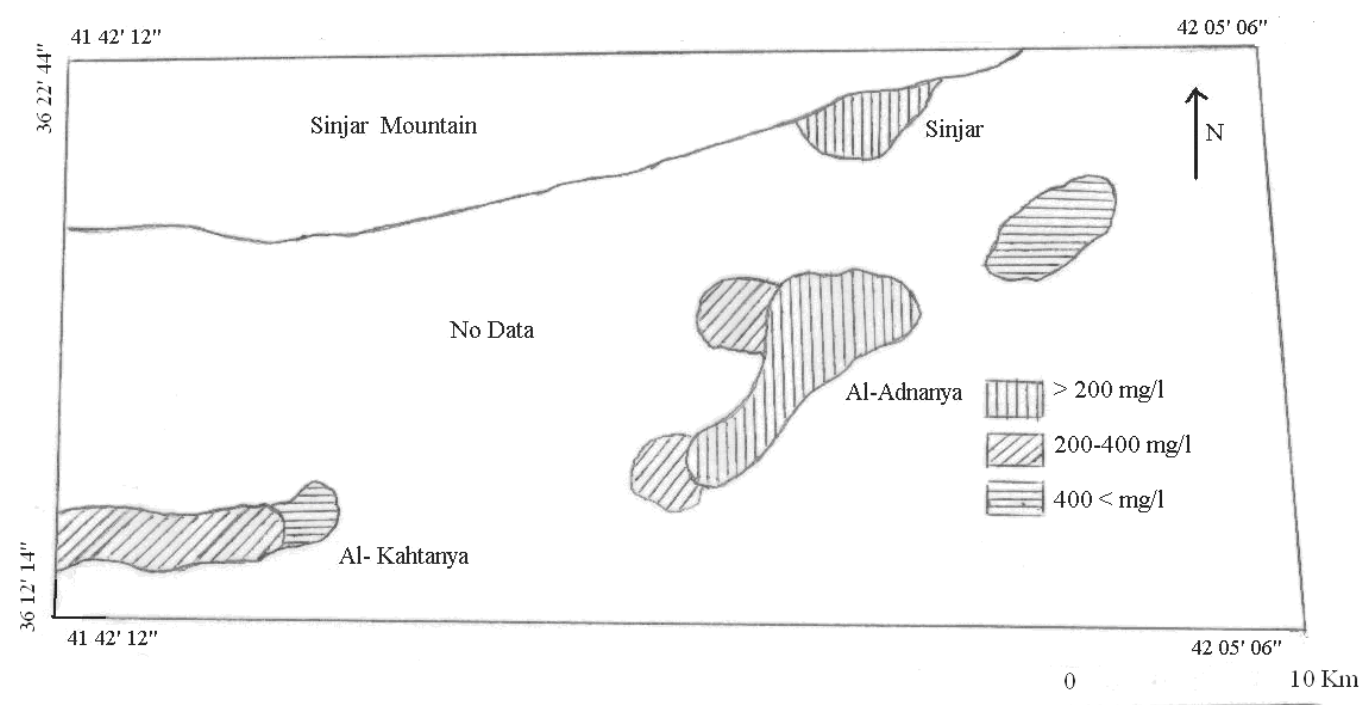

Fig. 10: Distribution of sulphate $\left(\mathrm{SO}_{4}\right)$ in Injana aquifer.

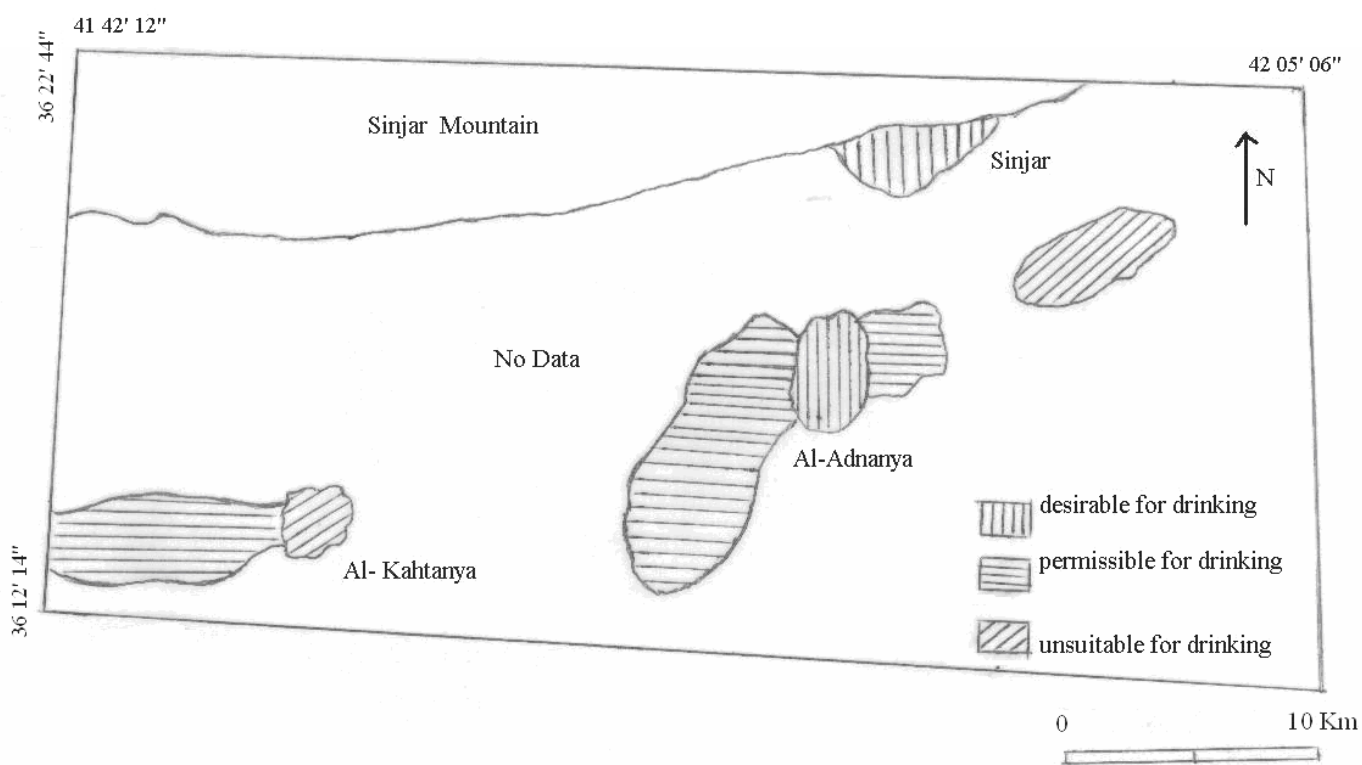

Fig. 11: water quality map of Injana aquifer.

\section{HYDROGEOCHEMICAL EVALUATION}

The $\left(\mathrm{HCO}_{3} / \mathrm{Cl}\right)$ ratio can be considered as a factor to delineate the areal extent of recharge and discharge zone. If the above ratio is more than unity then such zone is considered a recharge area, but if the ratio is less than unity it is considered as discharge zone (Rao, 2007). In the studied area the ratio $\left(\mathrm{HCO}_{3} / \mathrm{Cl}\right)$ calculated and it was found that ten water samples $71 \%$ have values more than 1 and ranges between 1.14 to 3.79 with a mean of 2.27 which indicate a deficiency of $\mathrm{Cl}^{-}$in the water and gives an idea of recharge area, while four water samples 29\% have values less than 1 and ranges between 0.38 to 0.74 with a mean of 0.55 which indicate a excess of $\mathrm{Cl}^{-}$of in the water and gives an idea of discharge zone, (Table 12 and 13). 
Table 12: Hydrochemical factor for identifying recharge and discharge zones.

\begin{tabular}{|c|c|c|c|l|c|}
\hline $\begin{array}{c}\text { EC } \\
\mu \mathrm{mohs} / \mathrm{cm}\end{array}$ & $\begin{array}{c}\text { TDS } \\
\mathrm{mg} / \mathrm{l}\end{array}$ & $\begin{array}{c}\text { Hydrogeochemical } \\
\text { pattern }(\mathrm{meq} / \mathrm{l})\end{array}$ & $\mathrm{HCO}_{3} / \mathrm{Cl}$ & \multicolumn{1}{|c|}{ Remarks } & Samples\% \\
\hline$<1791$ & $<1000$ & Low content $\mathrm{Cl}^{-}$ & 2.27 & Recharge zone & 71 \\
\hline$>1703$ & $>1000$ & High content $\mathrm{Cl}^{-}$ & 0.55 & Discharge zone & 29 \\
\hline
\end{tabular}

Table 13: Hydrochemical ratio of ground water samples.

\begin{tabular}{|l|c|c|c|c|}
\hline \multicolumn{1}{|c|}{ Wells. } & & $\mathrm{Cl}-(\mathrm{Na}+\mathrm{k}) / \mathrm{Cl}$ & $\begin{array}{c}\mathrm{Cl}-(\mathrm{Na}+\mathrm{k}) / \mathrm{CO}_{3}+ \\
\mathrm{HCO}_{3}\end{array}$ \\
\hline 1- Al-Jazera & 1.97 & 2.29 & -0.39 & -0.19 \\
\hline 2-Sinjar & 3.79 & 0.30 & -0.06 & -0.01 \\
\hline 3-Domies & 2.73 & 0.41 & -0.03 & -0.01 \\
\hline 4- Rambosy & 1.96 & 0.65 & -0.16 & -0.08 \\
\hline 5-Al-Adnanya 1 & 2.45 & 0.68 & -0.13 & -0.05 \\
\hline 6- Al-Adnanya 2 & 1.14 & 1.06 & 0.73 & 0.63 \\
\hline 7- Al-Adnanya 3 & 2.95 & 1.18 & -0.43 & -0.14 \\
\hline 8-Al-Kahtanya 1 & 1.33 & 2.18 & 0.21 & 0.15 \\
\hline 9- Al-Kahtanya 2 & 1.71 & 3.97 & -0.64 & -0.37 \\
\hline 10- Karabbazar & 2.74 & 1.13 & -0.19 & -0.07 \\
\hline 11- Telkasab 1 & 0.38 & 4.71 & 0.53 & 1.39 \\
\hline 12- Telkasab 2 & 0.61 & 4.50 & 0.32 & 0.52 \\
\hline 13- Al- Hatmeea & 0.74 & 1.53 & 0.62 & 0.84 \\
\hline 14- Bluij & 0.47 & 5.95 & 0.41 & 0.87 \\
\hline
\end{tabular}

The ion exchange between ground water and its host environment during residence or travel can be understood by studying Indices of Base Exchange (IBE) suggested by (Schoeller, 1965). The Indices of Base Exchange were calculated using the two formulae

$\mathrm{IBE}-\mathrm{I}=\mathrm{Cl}-(\mathrm{Na}+\mathrm{K}) / \mathrm{Cl}$

IBE-II $=\mathrm{Cl}-(\mathrm{Na}+\mathrm{K}) / \mathrm{HCO}_{3}+\mathrm{CO}_{3}$

(all values expressed in meq/l ).

When there is exchange between sodium and potassium in ground water with calcium and magnesium in the aquifer mineralogy, both of the indices are positive, indicate absence of Base Exchange reaction (reverse ion exchange).

If the exchange takes place between calcium and magnesium in ground water with sodium and potassium in aquifer mineralogy, the indices will be negative, indicating ion exchange. In the study area samples number $\mathrm{w}_{6}, \mathrm{w}_{8}, \mathrm{w}_{11}, \mathrm{w}_{12}, \mathrm{w}_{13}$ and $\mathrm{w}_{14}$ shows positive ratios indicating reverse ion exchange while the rest of samples shows negative ratios, indicating the occurrence of the cation exchange which leads to enrichment of $\mathrm{Na}$ due to the ion exchange with some clays, (Table 13). (Fig. 12) shows increase concentration of $\mathrm{Na}^{+}$and $\mathrm{Cl}^{-}$along ground water flow path from North toward South. 


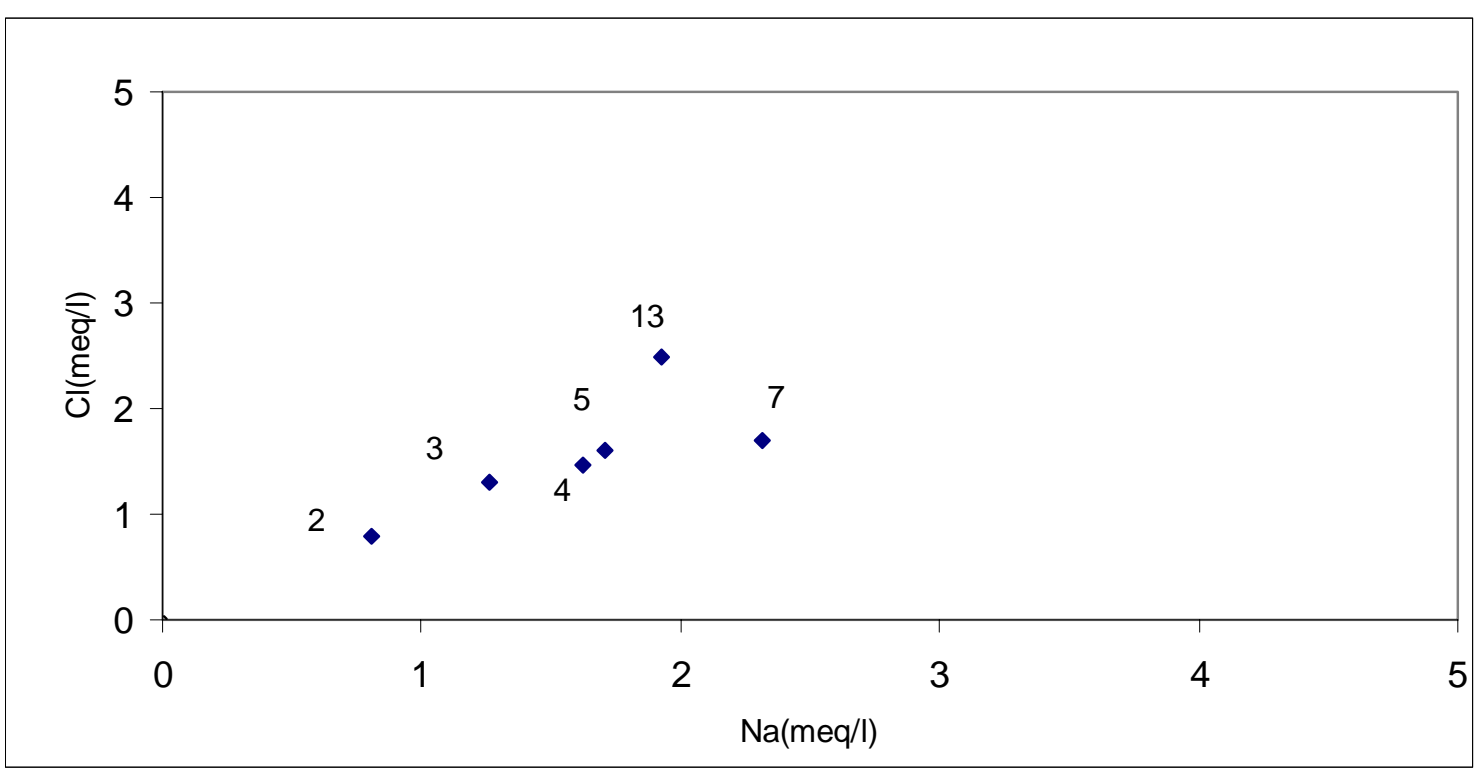

Fig. 12: Increase concentration of $\mathrm{Na}^{+}$and $\mathrm{Cl}^{-}$in ground water along ground water flow path from north toward south.

\section{CONCLUSIONS}

The present study on the ground water quality shows that the water is of both bicarbonate and sulphate type, the latter being the dominant. The first type has TDS , TH, $\mathrm{Mg}^{++}$and $\mathrm{SO}_{4}^{-2}$ less than, 615, $332,30.4$ and $129.4 \mathrm{mg} / \mathrm{l}$ respectively, while the second type has TDS,TH, $\mathrm{Mg}^{++}$and $\mathrm{SO}_{4}^{-2}$ more than 661,374,41.6 and $195.2 \mathrm{mg} / \mathrm{l}$ respectively. Also the $\left(\mathrm{SO}_{4} / \mathrm{HCO}_{3}\right)$ ratio is less than unity in bicarbonate water type, whereas this ratio is more than unity in sulphate water type

The dendrogram obtained from cluster analysis reveals two distinct types of ground water in the study area

Type I : TDS-TH-EC-Ca- Mg- $\mathrm{SO}_{4}-\mathrm{Na}-\mathrm{K}-\mathrm{Cl}$

Type II: $\mathrm{HCO}_{3}$.

Water quality mapping for Injana aquifer showes wells located in Sinjar, Domise and Rambosy are of good quality water (desirable for drinking), while wells located in Al-Adnanya and Al-Jazera are not exceeding maximum permissible limit and wells located in Telkasab and Al-Kahtanya are considered of bad water quality (unsuitable for drinking ).

Withdrawal of ground water exceeds the rate of recharge (overpumping) contribute in deteriorating ground water quality, as the water table declines with overpumping the water may be drawn to the well from deeper parts of the aquifer. More often the ground water has higher TDS concentration at higher depths because of slow circulation.

About 29\% of the wells of the study area located in discharge zone based on hydrochemical ratio $\left(\mathrm{HCO}_{3} / \mathrm{Cl}\right)$ which is less than unity, while the rest of the wells located in recharge zone based on this ratio which is more than unity.

Drilling wells for drinking water from Telkasab, Al-kahtanya and Bluij are useless due to containing brackish water. Adopting the technique of rain water harvesting which is an essential element in water strategy, could not only restore the ground water condition by infiltration and recharge water, but also mitigate the inferior quality of the 
ground water. This technique improve the ground water conditions as well as to reducing the brackishness of the waters.

\section{REFFERENCES}

APHA, 1975. Standard Methods for the Examination of Water and Waste Water. American Health Association, $14^{\text {th }}$. Ed., Washington, 759p.

Awad, J.H, 1984. Hydrogeology of South Sinjar Plain with a Mathematical Model, M.Sc. .Thesis, Mosul University, 177 p.

Buday, T. 1980. The Regional Geology of Iraq, Stratigraphy and Paleogeography, Mosul University Press, Mosul, 445p.

Davis, J.C, 1973. Statistics and Data Analysis in Geology. Wiley, New York, pp. 456- 467.

Davis, S.N. and Dewiest, R.J.M., 1966. Hydrogeology. John Wiley and Sons, New York, 463p.

Eriksson, E, 1985. Principle and Applications of Hydrochemistry. Chapman and Hall Ltd, New York, 187p.

General Directory of Water in Nienvia 2005. Rural Section Unpublished Data.

GEOSERV, 1996. Geological Map of Mosul Quadrangle, Scale 1:250,000 Printed and Published in the Establishment of Geological Survey and Mining Baghdad, Iraq.

Jassim, S.Z. and Goff, J., 2006. Geology of Iraq, Dolin and Moravian Museum, Brno, Czech Republic 341p.

Jenkins, D.; Snoeyink, L., Fergus, J.F. and Leckic, J.O., 1980. Laboratory Manual Water Chemistry, John Wiley and Sons, New York, 183p.

Meteorological Records Station in Mosul City, 2003. Unpublished Climatic Information, from 1980- 2003 Mosul, Iraq.

Piper, A.M., 1944. A Graphical Procedure in the Geochemistry Interpretation of Water Analysis, Trn. Am. Geoph. Union Vol.25, pp. 914-924.

Rao N.S., 2007. Groundwater Quality as a Factor for Identification of Recharge Zones. Environmental Geosciences, Vol. 14, No. 2, pp. 79-90.

Sarkar, B.C; Mahanta, b.N; Saikia, k; Paul, P.R. and Singh G. 2007. Geo-Environmental Quality Assessment in Jharia Coalfield, India, Using Multivariate Statistics and Geographic Information System. Environ. Geol. Vol. 51, pp.1177-1196.

Sawyer, G.N. and McCartly, D.L., 1967. Chemistry of Sanitary Engineers, ${ }^{2}$ nd Ed., McGraw Hill, New York, 518p.

Schoeller H. 1965. Hydrodynamique Dans le karst (Econlement et Emmagasinement). Actes Colloques Dubrovnik, I., AIHS et UNESCO. (in french).

Subramani T, Elango L, Damodarasamy S.R. 2005. Groundwater Quality and its Suitability for Drinking and Agricultural Use in Chithar River Basin, Tamil Nadu, India. Environ. Geol. Vol. 47, pp.1099-1110.

Vogel, I. A., 1961. A Text Book of Quantitative Inorganic Analysis 3rd. ed. 1216 p.

WHO, 1983. Guidelines to Drinking Water Quality. World Health Organization, Geneva, $186 \mathrm{p}$. 